\title{
Treatment and provider choice in worker injury rehabilitation: A systematic literature review
}

\author{
Olwen Anderson $^{\mathrm{a}, \mathrm{b}, *, 1}$, Vanette McLennan ${ }^{\mathrm{a}, \mathrm{b}, 2}$ and Christine Randall ${ }^{\mathrm{a}, \mathrm{b}, 3}$ \\ ${ }^{a}$ School of Health Sciences and Social Work, Griffith University, Gold Coast, Queensland, Australia \\ ${ }^{\mathrm{b}}$ The Hopkins Centre, Menzies Health Institute Queensland, Queensland, Australia
}

Received 30 March 2021

Accepted 1 July 2021

Pre-press 24 November 2021

Published 11 January 2022

\begin{abstract}
.
BACKGROUND: In the face of significant costs for injured worker rehabilitation and its impact on society, ongoing examination of how rehabilitation is carried out is warranted.

OBJECTIVE: To review recent studies that explored the impact of the worker's choice in terms of provider and treatment on the outcome for the worker in injury rehabilitation.

METHOD: A systematic literature review was conducted using searches through electronic databases, with studies retrieved then subjected to a quality appraisal.

RESULTS: Nineteen studies were eligible for inclusion. Studies reviewed found that choice of provider or treatment generated more positive outcomes for workers, and workers preferred a treatment provider familiar with their care. The worker's ability to exercise choice was affected by conflict with other stakeholders and misalignment of expectations. The relationship between choice and costs was unclear, sometimes conflicting.

CONCLUSIONS: The impact of treatment and provider choice on outcomes for workers remains unclear. The worker's ability to choose may be hampered by systemic constraints, access to preferred providers, misalignment of stakeholder expectations, and the worker's ability to engage in decision making. Greater worker engagement in their rehabilitation could potentially reduce costs as well as improve psychosocial outcomes.
\end{abstract}

Keywords: Return to work, choice, outcome, rehabilitation, review, workers compensation

\footnotetext{
${ }^{1}$ Olwen Anderson https://orcid.org/0000-0001-6342-5004

${ }^{2}$ Vanette McLennan https://orcid.org/0000-0001-5078-9802

${ }^{3}$ Christine Randall https://orcid.org/0000-0001-6293-0359

*Address for correspondence: Olwen Anderson, School of Health Sciences and Social Work, Gold Coast Campus, Griffith University, Southport, Queensland 4215, Australia. Tel.: +61 427 558 870; E-mail: o.anderson@griffith.edu.au.
}

\section{Introduction}

In Australia, the cost of worker injury is significant, accounting for $4 \%$ of gross domestic product in 2013, with $77 \%$ of that cost borne by workers (Safe Work Australia, 2019). This impact extends beyond economics to psychosocial losses for workers, their families and society (Landstad et al., 2009). Despite reduction in the quantity of work injury claims over 
time, rates of return to work have remained static, and time off work for serious claims is increasing; prompting ongoing examination of how work injury rehabilitation is undertaken (Safe Work Australia, 2020).

Recovery from injury as well as return to employment and the income it provides are the goals of workplace injury rehabilitation (Neumark \& Savych, 2018) with work participation recognised for the psychosocial benefits it confers (Brede et al., 2014; Farholm et al., 2017; Gouin et al., 2017; Neumark et al., 2007). Both government and employers encourage return to work, with the worker expected to participate in their recovery in a self-determined manner (van Hal et al., 2012). Government policies compel prompt return to workforce participation and discourage dependence on welfare support (Buys et al., 2015; Byrnes \& Lawn, 2013; Landstad et al., 2009; van Hal et al., 2013). Employers also encourage timely return to work, impelled by the costs of rehabilitation and the sometimes-limited availability of alternative duties for injured workers during their recovery (Eaton et al., 2015). There is also a personal imperative encouraging prompt return to work: Since the demands of an employee's role can change over time, the longer their absence from work the more likely a gap has grown between the worker's capacity and the demands of the job (Landstad et al., 2009). Return to work as soon as feasible is therefore promoted from economic as well as psychosocial perspectives.

Client-centric approaches to worker injury are a growing focus of rehabilitation, perceived as improving the rate of return to work (Safe Work Australia, 2020). Yet the worker's preferences during rehabilitation may be constrained, for several reasons (Allen et al., 2014; Blanchette et al., 2017; Gilkey et al., 2008; Neumark et al., 2007; Tao et al., 2018), beyond the system's acknowledged complexity (Dean et al., 2019; Hutson \& Dunning, 2020; MacEachen et al., 2013). Firstly, the injured worker may have little experience of self-advocacy and limited formal education that could enable them to meet the normative expectations of the system structure (van Hal et al., 2012). Also, there may be a shortage of information available to them, their illness or injury may distort their ability to exercise rational choice, their cultural beliefs and values may influence their preferences, and misalignment of objectives may be occurring between the worker and the system (MacEachen et al., 2013). The worker is expected to make decisions in an environment where choice may be systemically obstructed, and the options available may not be meaningful to them.

The tension engendered by this situation can lead to disempowerment (van Hal et al., 2012), passive participation (Jakobsson et al., 2008) and recurrent return to rehabilitation support following an inappropriate placement (Buys et al., 2003), further increasing cost to the economy (Ipsen \& Goe, 2016). This conundrum calls for further investigation into the factors which influence a timely and effective return to work (Cancelliere et al., 2016).

This review was undertaken to explore recent research on the nexus between treatment and provider choice and the outcome for the worker in injury rehabilitation. For the purpose of this review, choice in the sphere of worker injury rehabilitation has been defined as self-determination; that is, having the capacity as well as opportunity to choose in the absence of restraint (Power, 2013; Shogren et al., 2015). Worker injury rehabilitation is defined as participation in the rehabilitation or workers' compensation system, including medical treatment following a physical or mental injury incurred while working. Outcomes are considered as the psychosocial outcomes and sense of satisfaction for the worker as well as the monetary cost of rehabilitation. To guide this review, a central research question was developed: What is the impact of the worker's choice in terms of provider and treatment on the outcome for the worker in injury rehabilitation?

\section{Method}

This review was methodical in its approach to collating and assessing the literature for inclusion, providing a more systematic, reproducible approach than a narrative review. The systematic design included a research question, a methodological approach to collating and assessing the literature, and inclusion of a quality appraisal (Arksey \& O’Malley, 2005; Munn et al., 2018). Utilising a reproducible method enabled quantified mapping of the research landscape and gaps (Pickering \& Byrne, 2014), providing an objective approach more valuable than a subjective narrative review with an arbitrary approach to data collection (Hammersley, 2001).

Databases queried were CINAHL Complete, Proquest, Medline, Scopus and PsychINFO using search terms based around key constructs. For the construct of rehabilitation, search terms were vocational 
rehabilitation, workers compensation, return to work, occupational rehabilitation, or work rehabilitation. For the construct of choice, the search terms used were choice, selection, preference, decision, or option. For the construct of treatment, search terms were treatment, provider, or therapy. For the construct of outcome, effect, affect, consequence, result, or outcome. Variations and combinations of these terms were utilised. A librarian was engaged to aid in development of the search strategy.

Studies determined to meet the inclusion criteria were those concerned with the role of choice, empowerment, or self-determination during the process of occupational rehabilitation after a workplace injury. Studies concerning rehabilitation unrelated to work injury were excluded. An exception to this were studies undertaken in some northern European countries (Norway and Sweden) and the United Kingdom where workplace injury and non-work illness rehabilitation are treated within the same system; the studies retrieved did not segment their cohorts based on source of injury as work-related or otherwise. In consultation with the research team, at the time of commencement (2017) it was considered appropriate to capture studies published in the previous decade, i.e. since 2007. The search was repeated in July 2020 and did not produce additional articles meeting the inclusion criteria. Peer-reviewed original research studies written in English were included, whether quantitative, qualitative, or mixed methods. Also excluded were literature reviews, conference proceedings, books, theses, and grey literature.

Screening and quality appraisal were undertaken by the first author, in consultation with the second and third authors. The mixed methods appraisal tool (MMAT) (Pluye et al., 2009) was utilised to assess the quality of the extracted studies in a systematic manner (Souto et al., 2015).

\section{Results}

This search generated an initial 1,104 records. Of these, 438 were found to be duplicates. Of the remaining 666 , the vast majority were removed, upon consensus with the research team, as they were not original studies, were reviews, or did not relate to treatment or rehabilitation following a workplace injury. An additional eight studies were obtained from reviewing the reference lists of these papers, as well as checking for more recent citations of the sourced papers. The original database search was completed in October 2018. A re-run of the search in July 2020 did not identify any additional studies meeting the inclusion criteria. This resulted in a total of 19 papers eligible for analysis, summarised in the diagram (Liberati et al., 2009) in Figure 1. Table 1 provides a summary of the 19 studies retrieved. These final papers were collated by the first author in an Excel spreadsheet, enabling categorisation of themes in line with the method developed by Pickering (2014).

\subsection{General characteristics}

The 19 studies retrieved were diverse in their approaches: 15 quantitative descriptive studies, two qualitative and two mixed methods studies. Most research (14) was retrospective in nature, with eight of the studies conducted through examination of existing records such as databases retained by insurers, government boards and regulators. Six studies utilised a survey for data collection. Of the four studies using qualitative or mixed methods, one collected data via interviews, one via focus groups, one utilised observation of meetings and one study utilised action research. Two studies used validated scales to measure variables. Most studies (15) were conducted on the North American continent (USA and Canada), the remainder in Norway (2), Sweden (1) and England (1). No studies were captured from Asian cultures, but this may reflect restriction of the search to papers written in English.

\subsection{Quality appraisal}

Most of the studies were assessed as generally low in quality by the MMAT tool. A representation of their quality score is included in Table 1 , in a form recommended by the developer of the tool (Reporting the results of the MMAT (version 2018), 2020, 10 December). Generally, quality was low, with only two of the 19 scoring $100 \%$ across all quality criteria. Six studies scored less than 50. The average score achieved was 62 . Only five studies posed clear research questions. Of the two mixed methods studies, neither provided a rationale for choosing this research strategy. Of the quantitative studies, eight had a low risk of non-response bias, possibly because these studies obtained their data from examining existing records rather than other methods such as surveys. All studies that met the criteria were included in the review regardless of their MMAT score due to the limited number of studies available. 


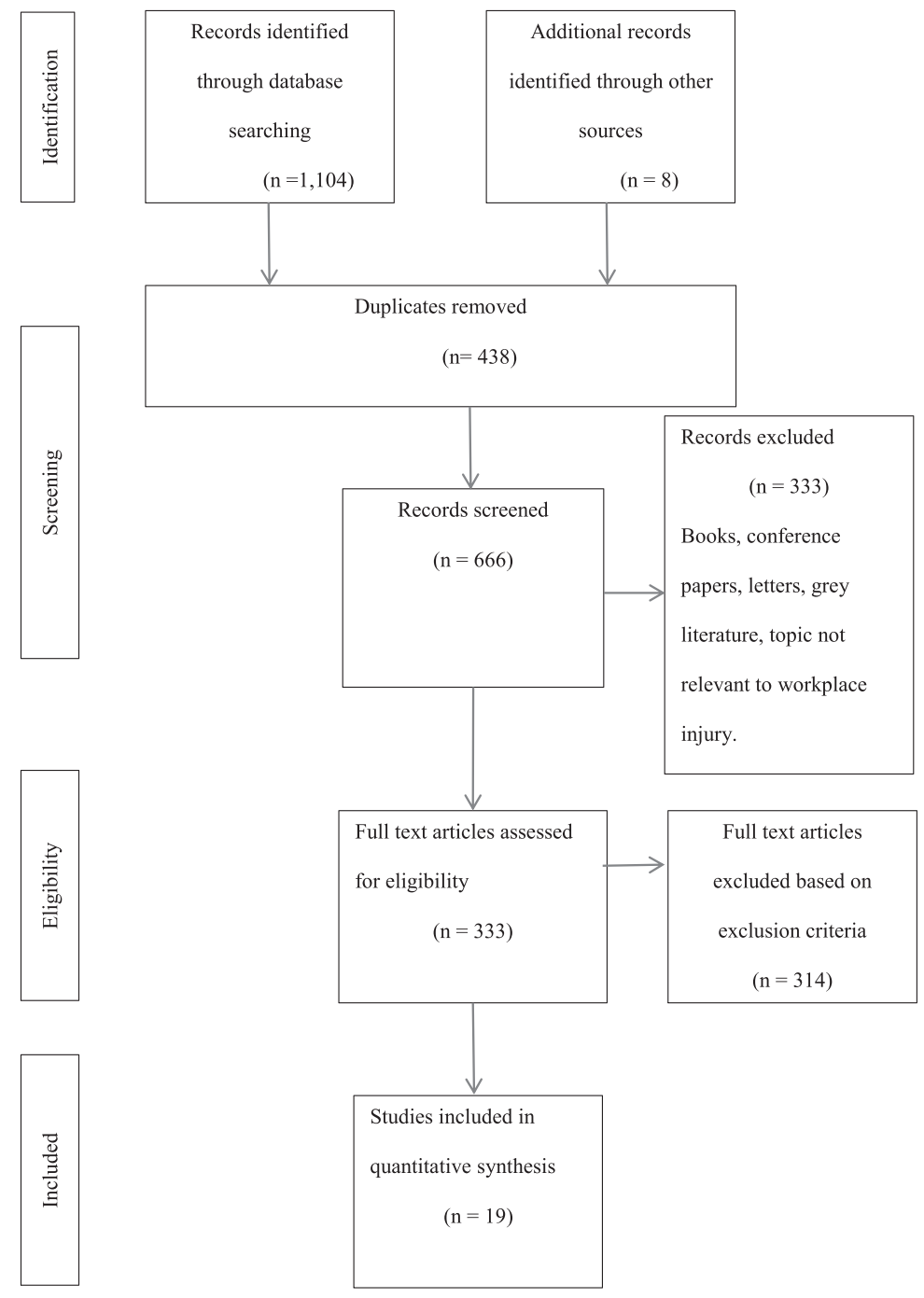

Fig. 1. PRISMA diagram.

\subsection{Research topics addressed}

A thematic matrix was developed within an Excel spreadsheet to help create a framework for analysis. Several themes emerged in this exploration of the relationship between treatment choice and outcomes in worker injury rehabilitation. These were the relationships between choice and cost, choice and outcomes, and factors which affected choice. Ten of the included studies focused on musculoskeletal injuries. This is unsurprising as musculoskeletal injuries dominate reasons for visits to a clinician (Allen et al., 2014) and workplace injuries (Blanchette et al., 2016; Blanchette et al., 2017; Branney \& Newell, 2009; Gilkey et al., 2008; Shraim et al., 2015). No studies examined purely psychological workplace injury. Six of the papers explored the impact of choice on costs. Five studies assumed or did not explore the capacity of the worker to engage in choice. Of the 17 quantitative studies, six were concerned with the impact of choice on costs. Most studies have been published in journal categories of occupational medicine, physical medicine and rehabilitation, and medical science.

\subsection{Relationship between treatment provider and costs}

Three papers considered the relationship between allowing employees to choose their own treatment 
Table 1

Studies reviewed

\begin{tabular}{|c|c|c|c|c|c|c|c|c|}
\hline $\begin{array}{l}\text { First author } \\
\text { and year }\end{array}$ & Purpose of study & Population & Type of study & $\begin{array}{l}\text { Data collection } \\
\text { method }\end{array}$ & Country & Nature of injury & Key findings & $\begin{array}{l}\text { Quality score } \\
\text { (MMAT) }\end{array}$ \\
\hline Allen 2014 & $\begin{array}{l}\text { Assess the cost of different } \\
\text { approaches to treatment of } \\
\text { low back problems }\end{array}$ & $\begin{array}{l}\text { Self-insured } \\
\text { workforce }\end{array}$ & $\begin{array}{l}\text { Retrospective, } \\
\text { quantitative }\end{array}$ & $\begin{array}{l}\text { Records } \\
\text { examined }\end{array}$ & $\begin{array}{l}\text { United } \\
\text { States }\end{array}$ & Musculoskeletal & $\begin{array}{l}\text { Reduced compliance with } \\
\text { guidelines results in higher } \\
\text { costs }\end{array}$ & $* * * * *$ \\
\hline $\begin{array}{l}\text { Blanchette } \\
2016\end{array}$ & $\begin{array}{l}\text { Identify influencers for } \\
\text { provider choice in } \\
\text { occupational back pain }\end{array}$ & $\begin{array}{l}\text { Workplace safety } \\
\text { and insurance } \\
\text { board claimants }\end{array}$ & $\begin{array}{l}\text { Retrospective, } \\
\text { quantitative }\end{array}$ & $\begin{array}{l}\text { Records } \\
\text { examined }\end{array}$ & Canada & Musculoskeletal & $\begin{array}{l}\text { Both injury and work-related } \\
\text { factors lead to employee } \\
\text { choice of treatment type }\end{array}$ & $* * *$ \\
\hline $\begin{array}{l}\text { Blanchette } \\
2017\end{array}$ & $\begin{array}{l}\text { Explore duration of } \\
\text { compensation and } \\
\text { prevalence of second } \\
\text { episode in back injury }\end{array}$ & $\begin{array}{l}\text { Workplace safety } \\
\text { and insurance } \\
\text { board claimants }\end{array}$ & $\begin{array}{l}\text { Retrospective, } \\
\text { quantitative }\end{array}$ & $\begin{array}{l}\text { Records } \\
\text { examined }\end{array}$ & Canada & Musculoskeletal & $\begin{array}{l}\text { Choice of treatment type } \\
\text { influences duration of } \\
\text { compensation period }\end{array}$ & $* * *$ \\
\hline $\begin{array}{c}\text { Branney } \\
2009\end{array}$ & $\begin{array}{l}\text { Explore self-care undertaken } \\
\text { by nurses for back pain and } \\
\text { what effect that choice has } \\
\text { on sick leave }\end{array}$ & $\begin{array}{l}\text { Nurses employed } \\
\text { at NHS hospital }\end{array}$ & $\begin{array}{l}\text { Prospective, } \\
\text { quantitative }\end{array}$ & Survey & $\begin{array}{l}\text { United } \\
\text { Kingdom }\end{array}$ & Musculoskeletal & $\begin{array}{l}\text { Choice of treatment type does } \\
\text { not influence rates of sick } \\
\text { leave }\end{array}$ & $* *$ \\
\hline Brede 2014 & $\begin{array}{l}\text { Evaluate usefulness of } \\
\text { proposed model for } \\
\text { managing treatment } \\
\text { decisions around } \\
\text { orthopaedic surgery for } \\
\text { musculoskeletal disorders }\end{array}$ & $\begin{array}{l}\text { Patients of } \\
\text { regional referral } \\
\text { centre }\end{array}$ & $\begin{array}{l}\text { Prospective, } \\
\text { quantitative }\end{array}$ & Action research & $\begin{array}{l}\text { United } \\
\text { States }\end{array}$ & Musculoskeletal & $\begin{array}{l}\text { Provision of choice regarding } \\
\text { surgery improves } \\
\text { psychosocial outcomes }\end{array}$ & ** \\
\hline Coutu 2015 & $\begin{array}{l}\text { Assess shared } \\
\text { decision-making behaviours } \\
\text { in occupational therapists }\end{array}$ & $\begin{array}{l}\text { Occupational } \\
\text { therapists and } \\
\text { their patients }\end{array}$ & $\begin{array}{l}\text { Retrospective, } \\
\text { quantitative }\end{array}$ & $\begin{array}{l}\text { Interview } \\
\text { recordings }\end{array}$ & Canada & Musculoskeletal & $\begin{array}{l}\text { Shared decision making is } \\
\text { influenced by patient's level } \\
\text { of education and ability to } \\
\text { advocate for themselves }\end{array}$ & $* *$ \\
\hline Coutu 2018 & $\begin{array}{l}\text { Exploring usefulness of a } \\
\text { proposed shared } \\
\text { decision-making model }\end{array}$ & Stakeholder group & $\begin{array}{l}\text { Prospective, } \\
\text { mixed } \\
\text { methods }\end{array}$ & $\begin{array}{l}\text { Survey and } \\
\text { focus groups }\end{array}$ & Canada & Musculoskeletal & $\begin{array}{l}\text { The shared decision-making } \\
\text { model proposed was largely } \\
\text { acceptable, with some } \\
\text { modification needed }\end{array}$ & $* *$ \\
\hline Eaton 2015 & $\begin{array}{l}\text { Explore what influences } \\
\text { worker choice of provider }\end{array}$ & Military veterans & $\begin{array}{l}\text { Retrospective, } \\
\text { quantitative }\end{array}$ & Survey & $\begin{array}{l}\text { United } \\
\text { States }\end{array}$ & $\begin{array}{l}\text { Physical and } \\
\text { psychological }\end{array}$ & $\begin{array}{l}\text { Expertise and accessibility } \\
\text { influences worker choice of } \\
\text { provider }\end{array}$ & $* * * *$ \\
\hline $\begin{array}{c}\text { Farholm } \\
2017\end{array}$ & $\begin{array}{l}\text { Explore patient perceptions } \\
\text { of provider support for } \\
\text { autonomy, and whether this } \\
\text { is associated with positive } \\
\text { change }\end{array}$ & $\begin{array}{l}\text { Participants in a } \\
\text { vocational } \\
\text { rehabilitation } \\
\text { program }\end{array}$ & $\begin{array}{l}\text { Prospective, } \\
\text { quantitative }\end{array}$ & $\begin{array}{l}\text { Formal } \\
\quad \text { measurement } \\
\text { scales }\end{array}$ & Norway & $\begin{array}{l}\text { Physical and } \\
\text { psychological }\end{array}$ & $\begin{array}{l}\text { More worker autonomy } \\
\text { results in better } \\
\text { psychosocial outcomes }\end{array}$ & $* * * * *$ \\
\hline
\end{tabular}


Table 1

(Continued)

\begin{tabular}{|c|c|c|c|c|c|c|c|c|}
\hline $\begin{array}{l}\text { First author } \\
\text { and year }\end{array}$ & Purpose of study & Population & Type of study & $\begin{array}{l}\text { Data collection } \\
\text { method }\end{array}$ & Country & Nature of injury & Key findings & $\begin{array}{l}\text { Quality score } \\
\text { (MMAT) }\end{array}$ \\
\hline Gilkey 2008 & $\begin{array}{l}\text { Explore the cost-related } \\
\text { differences between } \\
\text { chiropractic and allopathic } \\
\text { care for low back pain }\end{array}$ & Patients & $\begin{array}{l}\text { Retrospective, } \\
\text { quantitative }\end{array}$ & $\begin{array}{l}\text { Records } \\
\text { examined }\end{array}$ & $\begin{array}{l}\text { United } \\
\text { States }\end{array}$ & Musculoskeletal & $\begin{array}{l}\text { Chiropractic treatment takes } \\
\text { longer and costs more than } \\
\text { allopathic treatment }\end{array}$ & $* * *$ \\
\hline Gouin 2017 & $\begin{array}{l}\text { Explore how decision making } \\
\text { influences return to work }\end{array}$ & Stakeholders & $\begin{array}{l}\text { Retrospective, } \\
\text { qualitative }\end{array}$ & Interview & Canada & $\begin{array}{l}\text { Physical and } \\
\text { psychological }\end{array}$ & $\begin{array}{l}\text { Worker choice influences the } \\
\text { outcome of return-to-work } \\
\text { process }\end{array}$ & $* *$ \\
\hline $\begin{array}{l}\text { Jakobsson } \\
2008\end{array}$ & $\begin{array}{l}\text { Exploring the factors which } \\
\text { make female workers active } \\
\text { or passive decision makers } \\
\text { during vocational } \\
\text { rehabilitation }\end{array}$ & Injured workers & $\begin{array}{r}\text { Prospective, } \\
\text { qualitative }\end{array}$ & $\begin{array}{l}\text { Meetings } \\
\text { observed }\end{array}$ & Sweden & $\begin{array}{l}\text { Physical and } \\
\text { psychological }\end{array}$ & $\begin{array}{l}\text { People with an internal locus } \\
\text { of control have greater } \\
\text { ability to make decisions }\end{array}$ & $*$ \\
\hline Joshi 2016 & $\begin{array}{l}\text { Explore what factors predict } \\
\text { injured worker satisfaction } \\
\text { with rehabilitation }\end{array}$ & Injured workers & $\begin{array}{l}\text { Retrospective, } \\
\text { quantitative }\end{array}$ & Survey & United states & Unspecified & $\begin{array}{l}\text { Factors influencing } \\
\text { satisfaction include } \\
\text { perception of correct initial } \\
\text { diagnosis, explanation of } \\
\text { rights, and explanation of } \\
\text { treatment options }\end{array}$ & $* * *$ \\
\hline $\begin{array}{l}\text { Landstad } \\
2009\end{array}$ & $\begin{array}{l}\text { Investigate the experience of } \\
\text { professional support in } \\
\text { return to work }\end{array}$ & Injured workers & $\begin{array}{l}\text { Retrospective, } \\
\text { quantitative }\end{array}$ & Survey & Norway & $\begin{array}{l}\text { Physical and } \\
\text { psychological }\end{array}$ & $\begin{array}{l}\text { Rehabilitation experience } \\
\text { differs for workers with } \\
\text { physical versus } \\
\text { psychological injuries }\end{array}$ & $* * *$ \\
\hline $\begin{array}{l}\text { Neumark } \\
2007\end{array}$ & $\begin{array}{l}\text { What impact does choice of } \\
\text { provider have on workers } \\
\text { compensation costs and } \\
\text { outcomes }\end{array}$ & Injured workers & $\begin{array}{l}\text { Retrospective, } \\
\text { mixed } \\
\text { methods }\end{array}$ & $\begin{array}{l}\text { Records } \\
\quad \text { examined and } \\
\text { interviews }\end{array}$ & $\begin{array}{l}\text { United } \\
\text { States }\end{array}$ & $\begin{array}{l}\text { Physical and } \\
\text { psychological }\end{array}$ & $\begin{array}{l}\text { More worker choice leads to } \\
\text { higher costs, worse } \\
\text { outcomes }\end{array}$ & $*$ \\
\hline $\begin{array}{l}\text { Neumark } \\
2018\end{array}$ & $\begin{array}{l}\text { What are the effects of } \\
\text { provider choice policies on } \\
\text { workers compensation costs }\end{array}$ & Injured workers & $\begin{array}{l}\text { Retrospective, } \\
\text { quantitative }\end{array}$ & $\begin{array}{l}\text { Records } \\
\text { examined }\end{array}$ & $\begin{array}{l}\text { United } \\
\text { States }\end{array}$ & $\begin{array}{l}\text { Physical and } \\
\text { psychological }\end{array}$ & $\begin{array}{l}\text { Cost not higher with } \\
\text { employee choice of } \\
\text { provider except in } \\
\text { musculoskeletal injuries }\end{array}$ & $* * *$ \\
\hline Pourat 2007 & $\begin{array}{l}\text { Explore satisfaction with care } \\
\text { and perceptions of quality }\end{array}$ & Injured workers & $\begin{array}{c}\text { Retrospective, } \\
\text { quantitative }\end{array}$ & Survey & $\begin{array}{l}\text { United } \\
\text { States }\end{array}$ & $\begin{array}{l}\text { Physical and } \\
\text { psychological }\end{array}$ & $\begin{array}{l}\text { Satisfaction with care is } \\
\text { influenced by provider } \\
\text { relationship }\end{array}$ & $* *$ \\
\hline Shraim 2015 & $\begin{array}{l}\text { Examine the impact of } \\
\text { policies on costs and length } \\
\text { of disability }\end{array}$ & Injured workers & $\begin{array}{c}\text { Retrospective, } \\
\text { quantitative }\end{array}$ & $\begin{array}{l}\text { Records } \\
\text { examined }\end{array}$ & $\begin{array}{l}\text { United } \\
\text { States }\end{array}$ & Musculoskeletal & $\begin{array}{l}\text { Restricting choice of initial } \\
\text { provider reduces cost, but } \\
\text { allowing change of provider } \\
\text { results in lower cost and } \\
\text { better outcome }\end{array}$ & $* * *$ \\
\hline Тао 2018 & $\begin{array}{l}\text { Investigate if } \\
\text { employer-directed medical } \\
\text { care is associated with } \\
\text { lower claim costs }\end{array}$ & Injured workers & $\begin{array}{l}\text { Retrospective, } \\
\text { quantitative }\end{array}$ & $\begin{array}{l}\text { Records } \\
\text { examined }\end{array}$ & $\begin{array}{l}\text { United } \\
\text { States }\end{array}$ & $\begin{array}{l}\text { Physical and } \\
\text { psychological }\end{array}$ & $\begin{array}{l}\text { Employee choice of medical } \\
\text { care leads to high costs and } \\
\text { longer duration of claim }\end{array}$ & $* * *$ \\
\hline
\end{tabular}


provider or treatment type or both, and its impact on the cost of treatment. As these studies had differing aims, their consideration of the reason for the cost differential varied. All studies agreed that there were situations in which choice of provider could increase or reduce costs. One found that higher costs ensue where choice of medical provider is allowed but considered that this mostly occurred in complex back injury treatment (Neumark \& Savych, 2018). Another found that allowing complete choice of treatment provider increased costs yet permitting change of provider after initial treatment reduced costs (Shraim et al., 2015). Another considered that the highest cost occurred where the worker could choose their own treatment physician after an initial restriction, but that this group also incurred higher incidence of litigation (Tao et al., 2018). The same study proposed that inability to change providers could lead to mistrust and disputed decisions, thereby indirectly increasing costs. No cohesive conclusion was reached between the papers about the impact of provider choice on costs, although they conceded that the quality of the relationship between a provider and their patient could impact on treatment, thereby indirectly affecting costs.

Two studies considered whether there was a relationship between the type of treatment chosen and costs. One found that that chiropractic treatment incurred higher costs due to the larger number of treatments (Gilkey et al., 2008). Another assessed chiropractic treatment as incurring the lowest cost but proposed that the higher cost of medical treatment was due to non-compliance with established clinical treatment guidelines (Allen et al., 2014). As with consideration of provider choice, no clear picture emerged of the impact of treatment choice on costs. Studies could not concur on the relationship between provider or treatment choice and costs; yet the ability to exercise choice has been found to have a positive impact on return to work, regardless of the treatment undertaken (Brede et al., 2014).

\subsection{Relationship between choice and outcomes}

Whilst not as easily measured as costs, psychosocial factors and the worker's sense of satisfaction are an outcome of rehabilitation treatment. Two studies considered psychosocial outcomes of rehabilitation (Brede et al., 2014; Farholm et al., 2017), although what constituted psychosocial outcomes was not defined by either study. Five studies considered the impact of choice on worker satisfaction with treatment. One of those studies found that enablement of self-determination led to greater satisfaction (Farholm et al., 2017). Another considered that satisfaction was engendered when the worker perceived that their initial diagnosis was correct and their rights had been explained (Joshi et al., 2016). Three studies found that a better relationship between the injured worker and their provider resulted in greater understanding of treatment rationale, better compliance with treatment, and expectations around care more likely to be met (Gilkey et al., 2008; Neumark et al., 2007; Pourat et al., 2007). Not all studies agreed that worker satisfaction was necessary; one study concluded that treatment could be successful although unsatisfying for the worker (Landstad et al., 2009).

\subsection{Factors influencing choice}

The factors which influenced employee choice of provider were explored by three studies. Two found that ease of access to the provider influenced choice (Branney \& Newell, 2009; Eaton et al., 2015), the latter finding also that the sense of expertise of the provider influenced choice. Both injury and workrelated factors were found to influence the employee's choice of provider (Blanchette et al., 2016). In a qualitative study of women's experience of rehabilitation, it was proposed that women with an internal locus of control had greater ability to navigate the process of choosing (Jakobsson et al., 2008).

\section{Discussion}

In this systematic review of studies on the relationship between treatment or provider choice and outcomes in work injury rehabilitation, studies were found to focus on the impact of choice on costs and on outcomes for the worker, as well as the factors which impact on choice. A heterogeneous group of studies revealed conflicting findings, which has implications for the process of decision making to influence outcomes while containing costs.

It appears that the relationship between provider or treatment choice and costs is unclear, indeed conflicting. A consensus could not be generated from the studies retrieved about whether choice of provider or treatment increased or reduced costs and duration of treatment; however, the quality of the relationship between the worker and their provider was a contributing factor (Neumark et al., 2007; Neumark \& Savych, 2018; Shraim et al., 2015; Tao et al., 2018). 
A sole focus on cost as an outcome measure of rehabilitation is limiting, as rehabilitation also promotes other outcomes such as physical recovery, a return to productive employment and ongoing income (Brede et al., 2014; Farholm et al., 2017; Neumark \& Savych, 2018).

Positive outcomes for the worker, for the purpose of this review, were considered as a sense of satisfaction and psychosocial benefits. In terms of choice, a worker is more likely to be satisfied with treatment when they can choose their own provider, especially if they have seen that provider previously, regardless of the physical outcome of treatment (Allen et al., 2014). This perspective may emanate from the quality of the relationship between the provider and the injured worker (Pourat et al., 2007; Shraim et al., 2015). It has been proposed that participation in the process of choice may be the key to satisfaction more than simply provision of choice (Landstad et al., 2009). Support for patient autonomy has been linked to an increase in motivation (Farholm et al., 2017), and a degree of consensus in treatment planning and shared goals can lead to better outcomes (Gouin et al., 2017).

In considering the impact of the therapeutic relationship between a worker and their provider, there has been conjecture that an employer-chosen provider's loyalty may lie with the employer, creating an incentive for the provider to encourage earlier return to work. This may create a real or perceived conflict of interest. A provider chosen by the employee, in comparison, may be more lenient, more likely to meet the worker's expectations, there may be greater trust, and the manner of delivery of service provision may be more acceptable, exerting a positive influence on worker recovery (Neumark et al., 2007). Conversely, a systemic blockage to enabling change of provider has been proposed to lead to increased costs due to development of mistrust, disputations and even litigation (Shraim et al., 2015; Tao et al., 2018).

Factors that influence the worker's participation in decision making can impact the process of rehabilitation. Where there is the opportunity to exercise choice, the expertise of the provider and ease of accessibility are considered attractive to workers (Eaton et al., 2015). Also, the quality of the worker's relationship with their chosen practitioner influences the decisions they make, particularly when the worker perceives that their treating practitioner supports their autonomy and competence in making the appropriate choice (Farholm et al., 2017; Neumark \& Savych, 2018; Pourat et al., 2007). In a shared decision-making model, the patient and their practitioner exchange information, discuss options, benefits, risk and preferences in order to reach agreement about the treatment plan and goals (Coutu et al., 2018; Coutu et al., 2015). Collective decision making is fundamental to success in rehabilitation for return to work (Gouin et al., 2017). Yet conflicts may arise in the decision-making process as each stakeholder attempts to exercise what powers they have to seek imposition of their goals: Insurers have expectations around the cost of treatment and return to work, as do employers. Providers also may have expectations around preferred treatment to apply, and injured workers may have expectations about their treatment as well. Misalignment around expectations can result in action plans that are not directed towards a common goal (Coutu et al., 2018). It appears that although genuine choice is ideal in theory, in practice enabling that choice is not always achievable (Jakobsson et al., 2008). Yet choice does matter; it has a positive impact on satisfaction with care (Pourat et al., 2007), and greater autonomy results in better psychosocial outcomes (Farholm et al., 2017). The impact of choice on outcomes has implications for the costs as well as the outcomes for all stakeholders in rehabilitation.

\section{Strengths and limitations}

The strengths of this literature review lie in its expansion of the understanding of choice and its impact on worker injury rehabilitation outcomes; providing a foundation on which further research can be built.

The review had several limitations, including the narrow focus of the search limiting the quantity of studies for review, the generally heterogenous nature and low quality of the studies, variances in structures for compensation across countries, and the absence of a formal bias assessment.

It is possible that a broader search or a different review method could have resulted in a more comprehensive review. Firstly, search criteria may have excluded potentially important literature: Only papers in English were retrieved, with studies on this topic published earlier than 2007 excluded. Secondly, the heterogeneity and generally poor quality of studies undermined the potential for a more empirical review. Also, differences in approaches to health care internationally created some inconsistency: Studies undertaken in the comprehensive health and workplace injury management systems of some northern 
European countries and the British system did not differentiate between worker injury rehabilitation and illness rehabilitation, potentially obscuring whether outcomes varied in an integrated system. In Australia, Canada, and the United States worker injury treatment is managed in a separate system from illness treatment, making delineation of outcomes easier to discern. Finally, a formal bias assessment was not undertaken by this review.

\section{Conclusion}

This review explored studies undertaken on the impact of worker choice in terms of provider and treatment on outcomes for the worker. Psychosocial as well as economic costs make consideration of work injury rehabilitation imperative. However, very little scrutiny has been applied to the outcomes for the worker, be that in earnings, psychosocial outcomes, quality of life, employment post recovery and relief from pain. Existing studies on the relationship between choice and outcomes have provided conflicting data, whether considering financial costs, psychosocial benefits, or satisfaction. Generally, studies agree that some degree of choice of provider is positive, increasing worker satisfaction as well as reducing costs through prevention of disputes that could prolong time to return to work. However, several factors influence workers' ability to choose, including systemic constraints, access to preferred providers, the worker's ability to engage choice, and misalignment of expectations between stakeholders. These findings have implications for rehabilitation processes. To ensure economically and socially effective injury rehabilitation, more research is needed to explore the relationship between choice and outcomes for workers beyond costs; to consider their psychosocial recovery, the process of choice, and how choice influences the worker's participation in rehabilitation.

\section{Acknowledgment}

The authors would like to thank Bonnie Dixon, Griffith University librarian, for her assistance in building the search strategy.

\section{Conflict of interest}

The authors report no potential conflict of interest.

\section{Ethical declaration}

Ethical approval was not sought as this paper is a literature review.

\section{Funding}

None to report.

\section{Informed consent}

Informed consent was not sought as this paper is a literature review.

\section{References}

Allen, H., Wright, M., Craig, T., Mardekian, J., Cheung, R., Sanchez, R., Bunn, I. I. I. W. B., \& Rogers, W. (2014). Tracking low back problems in a major self-insured workforce: Toward improvement in the patient's journey. Journal of Occupational and Environmental Medicine, 56(6), 604-620. https://doi.org/ 10.1097/JOM.0000000000000210

Arksey, H., \& O’Malley, L. (2005). Scoping studies: Towards a methodological framework. International Journal of Social Research Methodology, 8(1), 19-32.

Blanchette, M., Rivard, M., Dionne, C. E., Hogg-Johnson, S., \& Steenstra, I. (2016). Workers' characteristics associated with the type of healthcare provider first seen for occupational back pain. BMC Musculoskeletal Disorders, 17(1), 1-15. https://doi. org/10.1186/s12891-016-1298-y

Blanchette, M., Rivard, M., Dionne, C. E., Hogg-Johnson, S., \& Steenstra, I. (2017). Association between the type of first healthcare provider and the duration of financial compensation for cccupational back pain. Journal of Occupational Rehabilitation, 27(3), 382-392. https://doi.org/10.1007/s10926016-9667-9

Branney, J., \& Newell, D. (2009). Back pain and associated healthcare seeking behaviour in nurses: A survey. Clinical Chiropractic, 12(4), 130-143. https://doi.org/10.1016/j.clch. 2009.12.002

Brede, E., Mayer, T. G., Shea, M., Garcia, C., \& Gatchel, R. J. (2014). Facilitating unequivocal and durable decisions in workers' compensation patients eligible for elective orthopedic surgery. Journal of Pain, 15(1), 49-58. https://doi.org/ 10.1016/j.jpain.2013.09.009

Buys, N., Hensby, S., \& Rennie, J. (2003). Reconceptualising the vocational rehabilitation process using a career development approach. Australian Journal of Career Development, 12(1), $36-48$.

Buys, N., Matthews, L. R., \& Randall, C. (2015). Contemporary vocational rehabilitation in Australia. Disability and rehabilitation, 37(9), 820-824. https://doi.org/10.3109/ 09638288.2014.942001

Byrnes, C., \& Lawn, S. (2013). Disability employment services in Australia: a brief primer. The Australian Journal 
of Rehabilitation Counselling, 19(01), 46-56. https://doi.org/ 10.1017/jrc.2013.4

Cancelliere, C., Donovan, J., Stochkendahl, M. J., Biscardi, M., Ammendolia, C., Myburgh, C., \& Cassidy, J. D. (2016). Factors affecting return to work after injury or illness: Best evidence synthesis of systematic reviews. Chiropractic and Manual Therapies, 24(1), 32. https://doi.org/10.1186/s12998016-0113-z

Coutu, M.-F., Légaré, F., Durand, M.-J., Stacey, D., Labrecque, M.E., Corbière, M., \& Bainbridge, L. (2018). Acceptability and feasibility of a shared decision-making model in work rehabilitation: A mixed-methods study of stakeholders' perspectives. Journal of Occupational Rehabilitation, 1-12. https://doi.org/ 10.1007/s10926-018-9770-1

Coutu, M.-F., Légaré, F., Stacey, D. P., Durand, M. J., \& Labrecque, M.E. (2015). Occupational therapists' shared decision-making behaviors with patients having persistent pain in a work rehabilitation context: A cross-sectional study. Annals of Physical and Rehabilitation Medicine, 58, e37-e37. https://doi.org/ 10.1016/j.rehab.2015.07.094

Dean, A.-M., Matthewson, M., Buultjens, M., \& Murphy, G. (2019). Scoping review of claimants' experiences within Australian workers' compensation systems. Australian Health Review, 43(4), 457-465. https://doi.org/10.1071/AH17244

Eaton, J. L., Mohr, D. C., Gallarde, S., \& Hodgson, M. J. (2015). Impact of clinical quality on employee choice of providers for workers' compensation-related medical care. Journal of Occupational and Environmental Medicine, 57 Suppl 3S(3), S31-S35. https://doi.org/10.1097/JOM.0000000000000387

Farholm, A., Halvari, H., Niemiec, C. P., Williams, G. C., \& Deci, E. L. (2017). Changes in return to work among patients in vocational rehabilitation: A self-determination theory perspective. Disability and rehabilitation, 39(20), 2039-2046. https:// doi.org/10.1080/09638288.2016.1215559

Gilkey, D., Caddy, L., Keefe, T., Wahl, G., Mobus, R., Enebo, B., Duvall, K., \& Griffiths, K. (2008). Colorado workers' compensation: medical vs chiropractic costs for the treatment of low back pain. Journal of Chiropractic Medicine, 7(4), 127-133. https://doi.org/10.1016/j.jcm.2008.06.002

Gouin, M.-M., Coutu, M.-F., \& Durand, M.-J. (2017). Returnto-work success despite conflicts: an exploration of decisionmaking during a work rehabilitation program. Disability and rehabilitation, 1-11. https://doi.org/10.1080/09638288.2017. 1400592

Hammersley, M. (2001). On'systematic'reviews of research literatures: a'narrative'response to Evans \& Benefield. British educational research journal, 27(5), 543-554.

Hutson, M. M., \& Dunning, T. (2020). Using new methods of communication to improve outcomes in workers' compensation case management. Professional Case Management, 25(3), 179-183.

Ipsen, C., \& Goe, R. (2016). Factors associated with consumer engagement and satisfaction with the vocational rehabilitation program. Journal of Vocational Rehabilitation, 44(1), 85-96. https://doi.org/10.3233/JVR-150782

Jakobsson, B., Bergroth, A., Ekholm, J., Ekholm, K. S., \& Svedlund, M. (2008). Multi-professional vocational rehabilitation group meetings with female clients: a qualitative study. Work, 30(4), 413.

Joshi, A. B., McCormick, Z. L., Sully, K., Garvan, C., \& Plastaras, C. T. (2016). Factors that predict satisfaction with medical Care: Data from 27,212 injured workers surveyed for 14 years.
Journal of Occupational and Environmental Medicine, 58(1), 101-107. https://doi.org/10.1097/JOM.0000000000000578

Landstad, B., Hedlund, M., Wendelborg, C., \& Brataas, H. (2009). Long-term sick workers experience of professional support for re-integration back to work. Work, 32(1), 39-48. https:// doi.org/10.3233/WOR-2009-0814

Liberati, A., Altman, D. G., Tetzlaff, J., Mulrow, C., Gøtzsche, P. C., Ioannidis, J. P., Clarke, M., Devereaux, P. J., Kleijnen, J., \& Moher, D. (2009). The PRISMA statement for reporting systematic reviews and meta-analyses of studies that evaluate health care interventions: explanation and elaboration. Journal of clinical epidemiology, 62(10), e1-e34.

MacEachen, E., Kosny, A., Ferrier, S., Lippel, K., Neilson, C., Franche, R.-L., \& Pugliese, D. (2013). The ideal of consumer choice in social services: Challenges with implementation in an Ontario injured worker vocational retraining programme. Disability \& Rehabilitation, 35(25), 2171-2179. https://doi.org/ 10.3109/09638288.2013.771704

Munn, Z., Peters, M. D., Stern, C., Tufanaru, C., McArthur, A., \& Aromataris, E. (2018). Systematic review or scoping review? Guidance for authors when choosing between a systematic or scoping review approach. BMC Medical Research Methodology, 18(1), 143.

Neumark, D., Barth, P. S., \& Victor, R. A. (2007). The impact of provider choice on workers' compensation costs and outcomes. Industrial and Labor Relations Review, 61(1), 121-142. https:// doi.org/10.1177/001979390706100107

Neumark, D., \& Savych, B. (2018). The effects of provider choice policies on workers' compensation costs. Health Services Research. https://doi.org/10.1111/1475-6773.13045

Pickering, C., \& Byrne, J. (2014). The benefits of publishing systematic quantitative literature reviews for $\mathrm{PhD}$ candidates and other early-career researchers. Higher Education Research \& Development, 33(3), 534-548.

Pluye, P., Gagnon, M.-P., Griffiths, F., \& Johnson-Lafleur, J. (2009). A scoring system for appraising mixed methods research, and concomitantly appraising qualitative, quantitative and mixed methods primary studies in mixed studies reviews. International Journal of Nursing Studies, 46(4), 529546. https://doi.org/10.1016/j.ijnurstu.2009.01.009

Pourat, N., Kominski, G., Roby, D., \& Cameron, M. (2007). Satisfaction with care and perceptions of quality among injured workers in California's workers' compensation system. Journal of Occupational and Environmental Medicine, 49(11), 1249-1256. https://doi.org/10.1097/JOM.0b013e3181 $566 \mathrm{~b} 5 \mathrm{e}$

Power, P. W. (2013). A guide to vocational assessment (Fifth ed.). Pro-Ed.

Reporting the results of the MMAT (version 2018). (2020, 10 December). In Mixed Methods Appraisal Tool Public WIKI. http://mixedmethodsappraisaltoolpublic.pbworks.com/w/ page/24607821/FrontPage

Safe Work Australia. (2019). Key WHS Statistics Australia. https:// www.safeworkaustralia.gov.au/doc/key-work-health-andsafety-statistics-australia-2019

Safe Work Australia. (2020). National return to work strategy 2020-2030. https://www.safeworkaustralia.gov.au/rtw

Shogren, K. A., Wehmeyer, M. L., Palmer, S. B., Forber-Pratt, A. J., Little, T. J., \& Lopez, S. (2015). Causal agency theory: Reconceptualizing a functional model of self-determination. Education and Training in Autism and Developmental Disabilities, 50(3), 251-263. 
Shraim, M., Cifuentes, M., Willetts, J. L., Marucci-Wellman, H. R., \& Pransky, G. (2015). Length of disability and medical costs in low back pain: Do state workers' compensation policies make a difference? Journal of Occupational and Environmental Medicine, 57(12), 1275-1283. https://doi.org/10.1097/ JOM.0000000000000593

Souto, R. Q., Khanassov, V., Hong, Q. N., Bush, P. L., Vedel, I., \& Pluye, P. (2015). Systematic mixed studies reviews: Updating results on the reliability and efficiency of the mixed methods appraisal tool. International Journal of Nursing Studies, 52(1), 500-501. https://doi.org/10.1016/j.ijnurstu.2014.08.010

Tao, X., Leung, N., Kalia, N., Lavin, R. A., Yuspeh, L., \& Bernacki, E. J. (2018). Is employer-directed medical care associated with decreased workers' compensation claim costs? Journal of Occupational and Environmental Medicine, 60(5), e232-e237. https://doi.org/10.1097/JOM.0000000000001247 van Hal, L., Meershoek, A., Nijhuis, F., \& Horstman, K. (2012). The 'empowered client' in vocational rehabilitation: the excluding impact of inclusive strategies. Health Care Analysis, 20(3), 213-230. https://doi.org/10.1007/s10728-011-0182-z

van Hal, L., Meershoek, A., Nijhuis, F., \& Horstman, K. (2013, 11). Disembodied abilities: Sick role and participation in 'activating' return-to-work practices. Social Science \& Medicine, 96, 9-16. https://doi.org/10.1016/j.socscimed.2013.07.003 